OPEN ACCESS

Edited by:

Luigi Daniele Notarangelo, Harvard Medical School, USA

Reviewed by:

Rafael Solana,

University of Córdoba, Spain

Emily Mace,

Baylor College of Medicine, USA

*Correspondence:

Andrea De Maria

de-maria@unige.it

Specialty section:

This article was submitted to NK and Innate Lymphoid cell Biology, a

section of the Journal frontiers in

Immunology

Received: 16 December 2016

Accepted: 23 February 2017

Published: 09 March 2017

Citation:

Bozzano F, Marras F and De Maria A (2017) Natural Killer Cell Development and Maturation Revisited: Possible Implications of a Novel Distinct $\mathrm{Lin}^{-} \mathrm{CD} 34^{+}$DNAM-1 ${ }^{\text {bright }} \mathrm{CXCR} 4^{+}$

Cell Progenitor.

Front. Immunol. 8:268.

doi: 10.3389/fimmu.2017.00268

\section{Natural Killer Cell Development and Maturation Revisited: Possible Implications of a Novel Distinct Lin-CD34+DNAM-1 $^{\text {bright }}{ }^{+}$XCR4+ Cell Progenitor}

\author{
Federica Bozzano ${ }^{1,2}$, Francesco Marras ${ }^{3}$ and Andrea De Maria ${ }^{2,4,5 *}$ \\ ${ }^{1}$ Department of Experimental Medicine (DIMES), University of Genova, Genova, Italy, ${ }^{2}$ Center of Excellence for Biomedical \\ Research (CEBR), University of Genova, Genova, Italy, ${ }^{3}$ stituto Giannina Gaslini, Genova, Italy, ${ }^{4}$ Clinica Malattie Infettive, \\ IRCCS AOU San Martino-IST Genova, Istituto Nazionale per la Ricerca sul Cancro, Genova, Italy, ${ }^{5}$ Department of Health \\ Sciences, DISSAL, University of Genova, Genova, Italy
}

Since the first description of natural killer (NK) cells, the view on their role in innate immunity has evolved considerably. In addition to first-line defense against transformed and pathogen-infected autologous cells, NK cells contribute to modulate adaptive immune responses and in some cases acquire specialized functions, including exhausted, adaptive, and decidual NK cells. NK cells derive from CD34+ progenitors, in vivo and in vitro; however, it is unclear whether the high phenotype diversity in vivo may be generated from these precursors alone. The recent characterization of a novel CD34+DNAM$1^{\text {bright }} \mathrm{CXCR} 4^{+}$precursor giving rise to apparently licensed and functional maturing NK cells may suggest the possibility for a higher than expected common lymphocyte precursor diversity and a consequently higher peripheral NK cell phenotype variability. Here, we review the evidences on NK cell central and peripheral development from $\mathrm{CD} 34^{+}$precursors and propose a possible updated reading frame based on the characterization of CD34+DNAM- $1^{\text {bright }} \mathrm{CXCR} 4^{+}$cell progenies, which favors the possibility of concurrent NK cell maturation from different CD34+ precursors.

Keywords: natural killer, NK cell development, CD34, DNAM-1, common lymphoid progenitors

\section{INTRODUCTION}

Natural killer (NK) cells, are a central component of the innate immune response (1) and constitute the first line of defense against a variety of tumors and microbial pathogens (2-5).

Over recent years, it has become clear that their role exceeds the boundaries of the original assignment to patrol the tissues as a first line of defense and rather also includes regulatory and editing functions of the innate and adaptive immune response.

Opposite to T or B cells, NK cells do not undergo somatic rearrangement of genes coding for antigen-specific receptors. Their functional characteristics include production and release of IFN $\gamma$ and TNF $\alpha$ and also G-CSF. In addition they may produce chemokines and IL-8, and under specialized and limited conditions also IL-10, IL-6, and IL-1. Following the identification and characterization of innate lymphoid cells (ILCs) into at least three lineages characterized by different phenotype, 
homing, and function $(6,7)$, NK cells have been proposed to be included into group 1 ILC (1) based on their expression of NFIL3, Tbet, and Eomes transcription factors $(1,8)$.

Human NK cells normally constitute $5-15 \%$ of peripheral blood (PB) lymphocytes. The majority of NK cells, are present in relative abundance in bone marrow (BM), liver, uterus, spleen, and lungs, as well as to a lesser extent in secondary lymphoid tissue (SLT), mucosa-associated lymphoid tissue, and the thymus. The classical description of NK cell phenotypes relies on CD56 and CD16 expression with the distinction of three broad phenotypes which include $\mathrm{CD} 16^{+/-} \mathrm{CD} 56^{\text {bright }}$ cells representing a minority of circulating and the majority of tissue-associated NK cells, CD $16^{+} \mathrm{CD} 56^{\mathrm{dim}}$ cells that constitute the majority of circulating $\mathrm{NK}$ cells and are viewed as effectors cells, and $\mathrm{CD} 16^{+} \mathrm{CD} 56^{-}$ exhausted NK cells that are poorly functional express low levels of natural cytotoxicity receptors (NCRs) and may become more abundant in PB during chronic infections, such as HIV-1 infection. A peripheral development of NK cells has been shown to take place beyond BM and lymphnode niches. NK cells undergo a progressive development of CD56 $6^{\text {bright }}$ into $\mathrm{CD} 56^{\mathrm{dim}} \mathrm{NK}$ cells with a progressive loss of NKG2A and concomitant progressive expression of KIRs, CD57, and NKG2C into terminally differentiated NK cells (9-11).

The original view encompassing a tripartite subset characterization has recently been updated in view of NK cell phenotype diversity. Using mass cytometry, it has become evident that in healthy adult humans a much larger number of distinct NK cell phenotypes are simultaneously present at any time. From 6,000 to 30,000 different NK cell phenotypes have been identified by mass in a single donor, and in any small group of persons up to 100,000 different NK cell phenotypes may be detected (12). In addition, by computer-assisted flow-cytometric analysis, at least 5-8 distinct subsets may be identified using a set of three NK cells specific monoclonal antibodies beyond CD16 and CD56 (11). This abundance of NK cell phenotype diversity is determined by combinatorial expression of the multitude of receptors and coreceptors present on their surface. In this regard, there are both evidences for an inherent intrinsic or genetically determined driver for the persistence of some phenotypes (mostly accounting for KIR variability), and for an extrinsic or environmental influence on the prevalence of other phenotypes supported by foreign antigenic stimulation supporting the diversity for NCR representation and expression (12).

\section{CD34 NK CELL PRECURSORS}

Similar to other blood cells, NK cells derive from hematopoietic stem cells (HSCs) and can be grown in vitro from lymphoidrestricted multipotent progenitors that may retain $\mathrm{B}$ and/or $\mathrm{T}$ lymphocyte developmental potential (13-15). The classical model of hematopoiesis postulates that the earliest fate decision toward NK cells downstream of HSCs is represented by the divergence of lymphoid and myeloid lineages. Erythroid and megakaryocyte lineages branch off before the lymphoid-myeloid split. This step is followed by myeloid-lymphoid divergence where common lymphoid progenitors (CLPs), and common myeloid progenitors (6) are generated. Accordingly, the CLP group would not include cell progenitors with myeloid potential. In contrast to mouse hematopoiesis, definitive evidence for a comprehensive model that best describes human hematopoiesis is still to be completely defined (16). Recently, a different pattern of cell maturation has been proposed following ex vivo and in vivo results in humans. Analysis of human cord blood (CB) and BM using seven distinct markers, including CD45RA, CD135 (Flt3), CD7, CD10, CD38, and CD90, allowed the identification of seven distinct progenitor cell classes (17). In this setting, some cells are described as multi-lymphoid progenitors (MLPs), defined by $\mathrm{CD} 34^{+} \mathrm{CD} 38^{-}$Thy $-1^{\text {neg-low }} \mathrm{CD} 45 \mathrm{RA}^{+}$, belong to the CLP group and are able, in specific culture conditions, to give rise to all lymphoid cells as well as monocytes, macrophages, and dendritic cells (DCs) $(18,19)$. Among these MLPs included in this last model, NK cells derive from CD34 ${ }^{+}$hematopoietic stem cells (HPC) precursors originally identified in BM (20). However, CD $34^{+}$ cells giving rise to NK cell progeny have been detected also in $\mathrm{PB}$, thymus, lymphnodes, CB, GALT, and decidua $(21,22)$. In addition, other reports indicate that $\mathrm{T}$ and $\mathrm{NK}$ cells are generated from non-characterized bipotent $\mathrm{T} / \mathrm{NK}$ common progenitors, which may circulate in $\mathrm{PB}$ of healthy donors (HDs), albeit at very low frequencies $(23,24)$. While it is agreed that $\mathrm{CD}^{+} 4^{+} \mathrm{NK}$ cell progenitors reside in the $\mathrm{BM}$, there is a less clear view on whether seeding of these cells into other organs generates organ-specific NK cell maturation, or whether a predefined CLP or MLP with specific developmental and homing characteristics would exit under certain conditions from the BM and specifically seed into the final sites of maturation.

\section{NK CELL MATURATION}

Distinct stages of development of NK cells from HPC have been described with an orderly and staged acquisition of NK cell markers, and distinct maturational stages (1). Five stages of human NK cell development have been described (25). Stage 1-2 $\mathrm{CD}^{2} 4^{+} \mathrm{CD} 45 \mathrm{RA}^{-/+} \mathrm{Cd} 10^{+/-} \mathrm{CD} 117^{-/+}$cells have been observed in human SLT and retain non-NK cell lineage potential since under optimal in vitro conditions they can develop into T and DC cells. This development potential is lost in the third stage in which may identify committed immature NK (iNK) cells.

The acquisition of the interleukin 15 (IL-15R) receptor beta chain (CD122) marks an important step of NK cell differentiation, since IL15 promotes NK cell differentiation, functional maturation, and survival in both mouse and human (26). Thus, IL-15R expression identifies an NK cell precursor subset defined by developmental potential in response to IL-15, by lack of functional immunophenotype observed in mature NK cells and by lack of other Lineage specific surface antigen as CD3, CD14, and CD19. Two populations of IL-15-responsive $\mathrm{Lin}^{-} \mathrm{CD} 94^{-} \mathrm{NK}$ differentiating intermediates have been identified $\left(\mathrm{Lin}^{-} \mathrm{CD} 34^{\mathrm{dim}} \mathrm{CD} 45 \mathrm{RA}^{+}\right.$ alpha4beta $7^{\text {bright }} \mathrm{CD} 117^{+} \mathrm{CD} 161^{+/-} \mathrm{CD} 94^{-}$stage 2 and $\mathrm{Lin}^{-} \mathrm{CD} 34^{-}$ alpha4beta7 ${ }^{-} \mathrm{CD} 117^{+} \mathrm{CD} 161^{+} \mathrm{CD} 94^{-}$stage 3$)$. They are enriched in the interfollicular $\mathrm{T}$ cell-rich areas of secondary lymphoid organs where their putative progeny, CD56 ${ }^{\text {bright }} \mathrm{CD} 94^{+} \mathrm{NK}$ cells, also resides $(25,27,28)$. This anatomical localization has been 
attributed to specific trafficking of BM derived NK cell precursors to SLT via high endothelial venules and would be mediated by high expression of CD62L on circulating $\mathrm{Lin}^{-} \mathrm{CD} 94^{-} \mathrm{NK}$ differentiating intermediates (28). NK cell differentiation then progresses by orderly acquisition of CD161, CD56, CD94/ NKG2A, NKp46, NKG2D, KIRs and functional receptors CD16 $(27,29,30)$. The role of CD56 during NK cell development is yet undefined while acquisition of CD94, which then persists on PB CD56 $6^{\text {bright }} \mathrm{NK}$ cells and is needed for surface expression of NKG2A or NKG2C, signals the transition to stage 4 in SLT and $\mathrm{NK}$ cell maturation is completed with transition from stage $4 \mathrm{CD} 56^{\text {bright }} \mathrm{CD} 16^{+/-}$to stage 5 in $\mathrm{CD} 56^{\mathrm{dim}} \mathrm{CD} 16^{+} \mathrm{NK}$ cells $(9,31)$. A source of possible confusion is represented by work showing that cells of myeloid lineage may, under certain specific conditions, generate NK cells in vitro (32). This work concentrates only on cord-blood CD34+ cells under particular conditions (32). The view that NK cells may be derived in vitro together with myelomonocytes without evidence for $\mathrm{T}$ cell growth reflects work by other groups as well $(27,33)$.

Some caution is needed when considering these models, which are nevertheless useful to provide a general scaffolding to understand NK cell peripheral maturation. Opposite to the model of peripheral $\mathrm{T}$ cell maturation from which it has been shifted for practical purposes, NK cell maturative migration between stages is not a one-way process. For example, NK cells may revert form terminal differentiation and, under favorable conditions in vitro (e.g., IL18 supplementation), may modify surface receptor expression with upregulation of CCR7, CD83, and CD25 and downregulation of CD16 (34). Furthermore, in vivo, NK cell education, epistatic interaction with KIR genes and viral infection or other environmental stimuli have a marked bearing on NK cell repertoire phenotype and activating and inhibitory receptor expression $(35,36)$.

An additional layer of entanglement to a linear model of NK cell development has been represented by the suggestion that NK cells may represent a subset of ILC (37). ILC have been shown in vitro derived from $\mathrm{CD} 34^{+}$cells isolated preferentially from the $\mathrm{CB}$ compared to $\mathrm{PB}$ (38). Indeed, the recent demonstration of the possibility of an elective ILC deficiency in humans without NK cell deficiency shows that ILCs might be dispensable in natural conditions and that developmental pathways for NK cell and ILC development are distinct (37).

\section{OUTLIERS TO A LINEAR SINGLE-CELL MODEL OF NK CELL DEVELOPMENT}

There are additional outliers to a model of sequential NK cell development that cannot be apparently reconciled with a singlecell maturation scheme for NK cells, so far. These include the observation of adaptive or memory-like NK cell responses, the appearance of $\mathrm{CD}^{-} 6^{-} \mathrm{CD} 16^{+}$exhausted NK cells in some clinical conditions, and the origin of NK cells in decidua.

In mice, infection with MCMV determines the expansion of specific NK cell subsets (39-41), which maintain for prolonged periods of time the ability to produce increased amounts of TNF $\alpha$ and IFN $\gamma$. This observation is reminiscent of memory $\mathrm{T}$ cell function thus suggesting a possible memory-like or adaptive feature of NK cells. This pattern has been observed also in humans and predominantly relates to HCMV previous infection (42-45). Human adaptive NK cell expansions are monomorphic. Indeed, only increased proportions of $\mathrm{NKG}_{2} \mathrm{C}^{+}$cells appear in $\mathrm{PB}$, irrespective of the different invading pathogens that have been so far able to induce such NK cell expansions, including HCMV or Hantavirus or Chikungunya $(46,47)$. NKG2C ${ }^{+} \mathrm{NK}$ cells expansions persist (48) after acute HCMV infection into latency, and may be observed also after BM transplantation $(48,49)$. Similar to virus-induced adaptive $\mathrm{NK}$ cells $(50,51), \mathrm{NKG}^{2} \mathrm{C}^{+} \mathrm{NK}$ cells may be obtained after cytokine induction (52). Active research in this area so far did not reach conclusive evidence that these memory-like NK cell expansions occur as a single terminal event along the previously described pathway of peripheral NK cell development. Additional work and efforts are needed to directly answer some crucial questions in this area. Specific trials and work will need to be designed to understand (a) whether the increase in adaptiveNKG2 ${ }^{+} \mathrm{NK}$ cells during Hantavirus or other RNA virus infections represents an $\mathrm{HCMV}$-independent event, or rather reflects a recall response of $\mathrm{NKG}_{2} \mathrm{C}^{+}$adaptive $\mathrm{NK}$ cells in $\mathrm{HCMV}^{+}$patients with latent infection, (b) whether only viruses or rather other pathogens may associate with $\mathrm{NKG}_{2} \mathrm{C}^{+}$ $\mathrm{NK}$ cell expansions, (c) why only $\mathrm{NKG}_{2} \mathrm{C}^{+}$adaptive $\mathrm{NK}$ cells represent a recall response to invading viruses with different antigenic and PAMP characteristics (e.g., HCMV is a DNA-virus, Chikungunya is a RNA virus, no shared molecular patterns have been described), and (d) what is the advantage in terms of virus control or host survival provided by this quite specific HCMVassociated adaptive NK cell response.

Another apparent outlier to sequential NK cell subset development is represented by $\mathrm{CD} 56^{\text {neg }} \mathrm{CD} 16^{+}$exhausted NK cells, which have been described for the first time over 20 years ago (53). These cells may represent up to $20-40 \%$ of all NK cells or $3-6 \%$ of all lymphocytes in $\mathrm{HIV}^{+}$patients while they represent a rare population in the $\mathrm{PB}$ of HDs. Immunophenotypic analyses revealed that cell surface receptors expressed on $\mathrm{CD} 56^{\text {neg }} \mathrm{CD} 16^{+}$ cells overlap with that of so-called "stage 3 " iNK cells and are able, albeit to a reduced extent, to kill target cells and produce chemokines (54). Thus, it appears unlikely that CD56 ${ }^{\text {neg }} \mathrm{NK}$ cells represent the progeny of iNK cells. Effector molecule expression by $C D 56^{\text {neg }}$ NK cells further support the possibility that these cells are more closely related to and share characteristics with more highly differentiated CD56 ${ }^{\mathrm{dim}} \mathrm{NK}$ cells. Additional comprehensive studies of this subset are needed, in order to clarify when and under which stimuli aberrant differentiation into $\mathrm{CD} 56^{\text {neg }} \mathrm{CD} 16^{+}$ NK cells occurs as well as whether it is reversible or not.

Natural killer cells also localize in differentiated tissues including non-pregnant endometrium (55). Following embryo implantation, decidualization of human endometrium is associated with a massive recruitment of NK cells that will build up and may represent as many as $50-90 \%$ of lymphoid cells present in decidual tissue. Decidual NK cells (dNK) numbers progressively decrease from mid-gestation onwards (56). dNK cells have unique phenotypic properties and functional profile and are CD56 ${ }^{\text {bright }} \mathrm{CD} 16^{+/-} \mathrm{KIR}^{+}$cells. 
Analysis of gene expression in $\mathrm{dNK}$ revealed relevant differences with both CD56 $6^{\text {bright }}$ and CD $56^{\mathrm{dim}}$ peripheral NK cell subset. CD9, galectin, alpha-1 integrin, and other adhesion molecules are over-expressed in $\mathrm{dNK}$ (57), express major activating NK receptors, including NKp46, NKp30, NKG2D, and DNAM-1, and contain high levels of perforin and granzymes (comparable to $\mathrm{CD} 56^{\mathrm{dim}}$ peripheral NK cells), but have a poor ability to kill classical NK target cells $(22,58-60)$. dNK cells are able to release high amounts of cytokines and chemokines (including IL-8, VEGF, SDF-1, and IP-10), which are involved in tissue remodeling, trophoblast migration, and/or neo-angiogenesis and placentation. Thus, dNK cells appear to play an unexpected role in vessel formation and tissue building rather than their classical defensive role and these findings further underline the plasticity of NK cells, possibly induced by the particular microenvironment. Whether $\mathrm{dNK}$ cells represent a peripheral differentiation of other NK subsets or whether they represent a specific lineage derivation from a common precursor is so far poorly understood.

\section{A NOVEL CD34+ PRECURSOR AND A NEW PERSPECTIVE}

Recently, a novel, previously uncharacterized CLP has been identified and is defined by $\mathrm{Lin}^{-} \mathrm{CD} 34^{+}$DNAM- ${ }^{\text {bright }} \mathrm{CXCR} 4^{+}$ markers (60). These precursors were found enriched in $\mathrm{PB}$ of patients with chronic inflammatory conditions of either infectious or non-infectious origin. Based on available data on $\mathrm{CD} 34^{+}$ cell maturation niches (61-64), the phenotype of these cells suggest that they represent recent migrants from BM that still retain CXCR4 and DNAM-1, which are derived from endosteal niches following bone remodeling during chronic inflammation (65, 66). In HSC, BM donor $\mathrm{Lin}^{-} \mathrm{CD} 34^{+} \mathrm{DNAM}-1^{\text {bright }}$ cells represent only a fraction $(15 \%)$ of mobilized $\mathrm{CD} 34^{+}$cells. A comparison of chemokine receptor expression provided clues to a different end-organ circulation of these cells compared to classical $\mathrm{CD}_{3} 4^{+} \mathrm{DNAM}^{-}$progenitors. Lin $^{-} \mathrm{CD} 34^{+} \mathrm{DNAM}-1^{\text {bright }} \mathrm{CXCR} 4^{+}$ cells appear to have the potential of trafficking not only into lymphnodes or GALT via CD62L/L interactions, but also (or rather) to peripheral inflamed tissues along fractalkine or IL-8 in view of their higher expression of CX3CR $1^{+}$and $C X C R 1^{+}$and lower proportion of CD62L.

Analysis of transcription factors of these novel CD $34^{+}$cells showed that, they have a different array of transcription factors, including Tbet and FoxP3 in addition to Id2, E4BP4, which are expressed in classical CD $34^{+} \mathrm{DNAM}^{-} \mathrm{CXCR} 4^{-}$cells purified from CB. A wide difference in transcriptional signature was further confirmed and expanded by microarray analysis of purified $\mathrm{CD} 34^{+}$cells. Interestingly, their abundant transcription of metalloproteases supports the idea of a direct exit in areas of osteoclast resorption. Further, and in line with previous reports that failed to pinpoint the exact nature of the progenitor cells $(29,67)$, this novel CLP could give rise to NK and T cells but not to myelomonocytes. On the contrary, $\mathrm{CB}$-derived $\mathrm{CD} 34^{+}$cells give rise in vitro only to NK cells and myelomonocytes but not to $\mathrm{T}$ cells or NKT cells.
Interestingly, when considering the characteristics of NK cells in vitro derived from these precursors, some remarkable differences are evident in comparison to NK cells derived from $\mathrm{CD}_{3} 4^{+} \mathrm{DNAM}^{-} \mathrm{CXCR} 4^{-}$progenitors. $\mathrm{Lin}^{-} \mathrm{CD} 34^{+} \mathrm{DNAM}-$ $1^{\text {bright }} \mathrm{CXCR} 4^{+}$derived maturing NK cells appear to have a much more mature and licensed phenotype, as they express KIRs and perforin, high levels of NCRs, DNAM-1 and NKG2D and also produce IFN $\gamma$ when triggered. These characteristics are unseen in maturing NK cells derived from $\mathrm{CD} 34^{+} \mathrm{CB}$ cells, which under the same culture conditions do not produce IFN $\gamma$, and are NCR low, $\mathrm{KIR}^{-}, \mathrm{DNAM}-1^{+/-}$, and NKG2D ${ }^{\text {low/neg }}$.

The question remains open on where $\mathrm{Lin}^{-} \mathrm{CD} 34^{+} \mathrm{DNAM}-$ $1^{\text {bright }}$ CXCR4 ${ }^{+}$cells fit with the classical known human NK cell progenitor hierarchy $(18,19)$ and why only very low levels of circulating CLP are detectable in HDs (16), while they may be greatly increased during systemic inflammation. According to the study by Doulatov et al. (19), Lin $^{-}$CD $34^{+}$DNAM$1^{\text {bright }} \mathrm{CXCR} 4^{+}$cells would (surprisingly) fit in the group of megakaryocyte/erythroid precursors, characterized by the $\mathrm{CD} 38^{+} \mathrm{CD} 10^{-} \mathrm{CD}^{-}$Flt3 phenotype similar to that of Lin ${ }^{-} \mathrm{CD} 34^{+} \mathrm{DNAM}-1^{\text {bright }}$ cells. In the absence of experiments carried out with culture conditions favoring different pathways for precursor differentiation, one cannot exclude that different progenies might be obtained.

Lin ${ }^{-} \mathrm{CD} 34^{+} \mathrm{DNAM}-1^{\text {bright }} \mathrm{CXCR} 4^{+} \mathrm{NK}$ cell progeny includes a full array of the classical phenotypes, including CD56 $6^{\text {bright }}$, CD56 $6^{\text {dull }}$, and $\mathrm{CD} 56^{-} \mathrm{CD} 16^{+} \mathrm{NK}$ cells subsets in addition to NKT $\mathrm{CD}^{+}{ }^{+} \mathrm{CD} 56^{+}$cells and to T cells but no cells of monocyte/myelomonocytic lineage (68). In view of the quite different phenotype of maturing NK cells derived from these precursors in vitro as compared to NK cells maturing from CD $34^{+} \mathrm{DNAM}-1^{-} \mathrm{CXCR} 4^{-}$ $\mathrm{CB}$ cells, it is tempting to hypothesize that the so far acknowledged model for NK cell differentiation and maturation from a single progenitor into all the known phenotypes and subsets may need renewed evaluation (Figures 1A,B).

Since an until recently uncharacterized CD34 precursor with distinct transcriptional signature and phenotype gives rise to NK cells with different phenotypic and functional characteristics, the hypothesis may be proposed that a parallel development of some NK cell phenotypes may take place in vivo from two different $\mathrm{CD} 34^{+}$precursors (i.e., Lin ${ }^{-} \mathrm{CD} 34^{+} \mathrm{DNAM}-$ $1^{\text {bright }} \mathrm{CXCR} 4^{+}$and $\left.\mathrm{CD} 34^{+} \mathrm{DNAM}-1^{-} \mathrm{CXCR} 4^{-}\right)$. It is, therefore, possible that a good number of the diverse NK cell phenotypes observed by mass cytometry (12) and possibly also some of the special subsets of NK cells observed in vivo may derive from different developmental stages of the two CD34 precursors. This view could be in line with the data by Doulatov et al. and Laurenti et al. $(18,19)$ where different CLP may give rise to different progenies but the same progeny may derive from different CLPs $(17,18)$. In addition, it should be underscored that recent work by Wu and colleagues (69) in elegant experiments of clonal tracking has identified a quite surprising origin of NK cells in macaques. Barcoding experiments show that in these animals, a progenitor different from $\mathrm{B} / \mathrm{T} /$ Myeloid lineage stem cells gives rise to $\mathrm{CD} 16^{+} \mathrm{CD} 56^{-} \mathrm{NK}$ cell progeny, and more importantly, parallel development of different NK cell phenotypes derive 


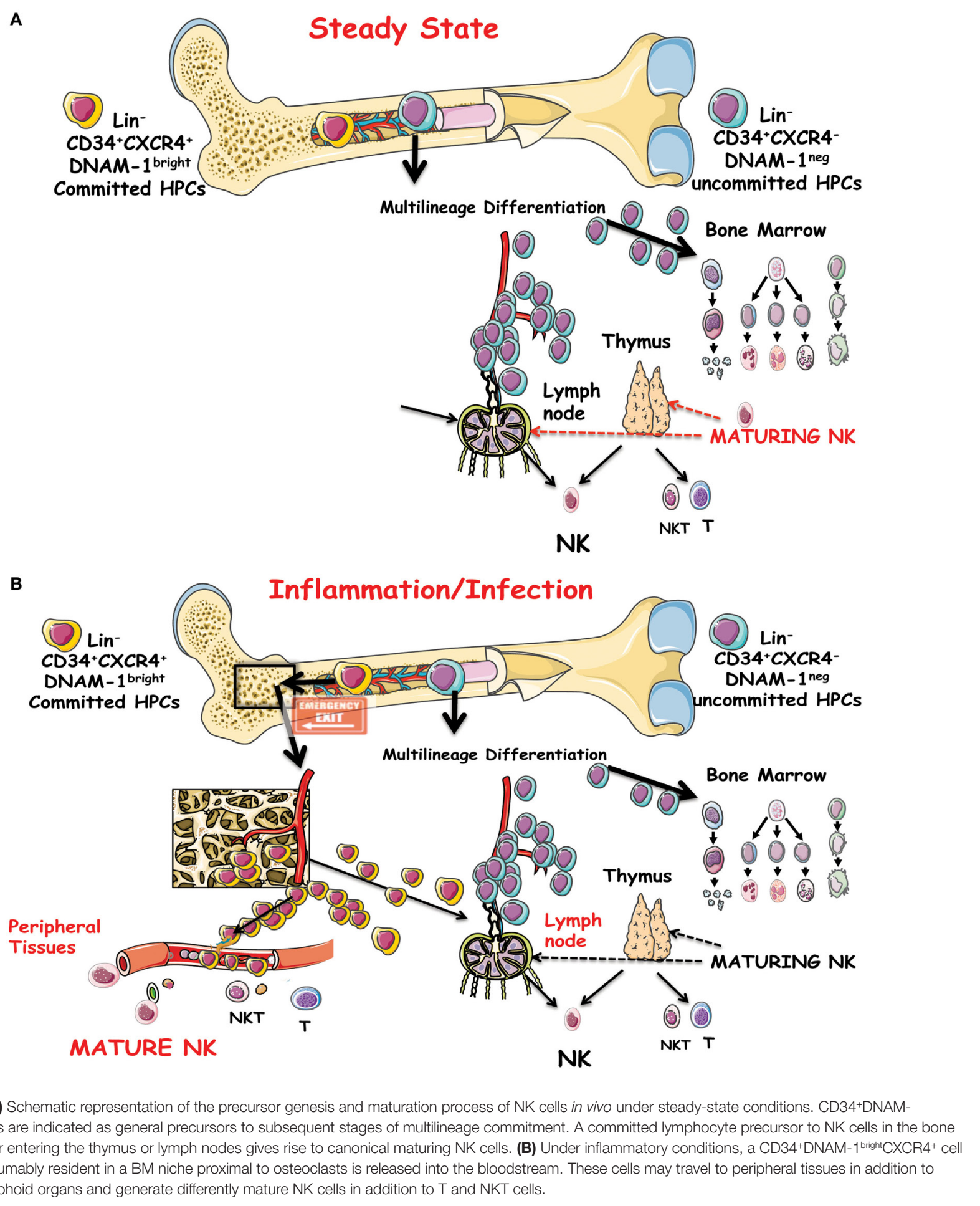

FIGURE 1 | (A) Schematic representation of the precursor genesis and maturation process of NK cells in vivo under steady-state conditions. CD34+DNAM$1^{-} \mathrm{CXCR} 4^{-}$cells are indicated as general precursors to subsequent stages of multilineage commitment. A committed lymphocyte precursor to NK cells in the bone marrow (BM) or entering the thymus or lymph nodes gives rise to canonical maturing NK cells. (B) Under inflammatory conditions, a CD34+DNAM- $1^{\text {bright }} \mathrm{CXCR} 4^{+}$cell precursor presumably resident in a BM niche proximal to osteoclasts is released into the bloodstream. These cells may travel to peripheral tissues in addition to secondary lymphoid organs and generate differently mature NK cells in addition to T and NKT cells.

from different progenitors. Given the difficulties in defining CD56 $6^{\text {bright }}$ and CD56 ${ }^{\text {dim }} \mathrm{NK}$ cell subsets in chimpanzees and macaques (70), the possible correlate of these findings on clonal tracking in macaques (69) needs to be evaluated with caution and may deserve evaluation also in other non-human primates.
Overall, the identification of a novel $\mathrm{CD} 34^{+}$cell, giving rise to NK cells with distinct characteristics may represent a parallel and concurrent reading frame for the established model of NK cell development from CD $34^{+}$cells to CD56 $6^{\text {bright }}$ to CD56 $6^{\text {dim }}$ NK cells $(9,10)$. 


\section{CONCLUDING REMARKS}

The identification of a novel $\mathrm{CD} 34^{+}$cell with distinct transcriptional and phenotypic characteristics to standard CD $34^{+}$ cells, endowed with the ability to generate NK cells of a special phenotype, opens new possibilities to improve our understanding of NK cell development and maturation, particularly under special or emergency conditions including systemic inflammation.

In this regard, several points need to be further understood to formulate a clear picture.

First, it will be important to understand whether additional different $\mathrm{CD} 34^{+}$precursors exist that may give rise preferentially to specific NK cell (or ILC) progenies or whether the identification of $\mathrm{Lin}^{-} \mathrm{CD} 34^{+} \mathrm{DNAM}-1^{\text {bright }} \mathrm{CXCR} 4^{+}$cells represents the only other $\mathrm{CD} 34^{+}$precursor, giving rise to NK cells. In other terms, we do not yet know whether these cells were the only ones that needed characterization in a sort of "dark side of the (BM) niche" that eluded identification until recently.

Next, it will be important to understand the relationship of these NK cells that are actively released from osteoclast niches to classical CD $34^{+}$DNAM- $1^{-}$NK cells that are passively released in the sinusoids.

Finally, careful analysis of NK cells developing from $\mathrm{Lin}^{-} \mathrm{CD} 34^{+} \mathrm{DNAM}-1^{\text {bright }} \mathrm{CXCR} 4^{+}$cells is needed to understand

\section{REFERENCES}

1. Yu J, Freud AG, Caligiuri MA. Location and cellular stages of natural killer cell development. Trends Immunol (2013) 34(12):573-82. doi:10.1016/j. it.2013.07.005

2. De Maria A, Bozzano F, Cantoni C, Moretta L. Revisiting human natural killer cell subset function revealed cytolytic CD56(dim)CD16+ NK cells as rapid producers of abundant IFN-gamma on activation. Proc Natl Acad Sci U S A (2011) 108(2):728-32. doi:10.1073/pnas.1012356108

3. Vankayalapati R, Klucar P, Wizel B, Weis SE, Samten B, Safi H, et al. NK cells regulate CD8+ T cell effector function in response to an intracellular pathogen. J Immunol (2004) 172(1):130-7. doi:10.4049/jimmunol.172. 1.130

4. Warfield KL, Perkins JG, Swenson DL, Deal EM, Bosio CM, Aman MJ, et al. Role of natural killer cells in innate protection against lethal Ebola virus infection. J Exp Med (2004) 200(2):169-79. doi:10.1084/jem.20032141

5. Moretta A. Natural killer cells and dendritic cells: rendezvous in abused tissues. Nat Rev Immunol (2002) 2(12):957-65. doi:10.1038/nri956

6. Zook EC, Kee BL. Development of innate lymphoid cells. Nat Immunol (2016) 17(7):775-82. doi:10.1038/ni.3481

7. Juelke K, Romagnani C. Differentiation of human innate lymphoid cells (ILCs). Curr Opin Immunol (2016) 38:75-85. doi:10.1016/j.coi.2015.11.005

8. Montaldo E, Vacca P, Moretta L, Mingari MC. Development of human natural killer cells and other innate lymphoid cells. Semin Immunol (2014) 26(2):107-13. doi:10.1016/j.smim.2014.01.006

9. Romagnani C, Juelke K, Falco M, Morandi B, D’Agostino A, Costa R, et al. CD56brightCD16- killer Ig-like receptor- NK cells display longer telomeres and acquire features of CD56dim NK cells upon activation. J Immunol (2007) 178(8):4947-55. doi:10.4049/jimmunol.178.8.4947

10. Moretta L. Dissecting CD56dim human NK cells. Blood (2010) 116(19):368991. doi:10.1182/blood-2010-09-303057

11. Gondois-Rey F, Granjeaud S, Rouillier P, Rioualen C, Bidaut G, Olive D. Multiparametric cytometry from a complex cellular sample: improvements and limits of manual versus computational-based interactive analyses. Cytometry A (2016) 89(5):480-90. doi:10.1002/cyto.a.22850 whether these presumably "tissue-bound" precursors follow a predefined program or rather whether signals delivered in peripheral tissues guide and sustain the development of NK cells with specialized function.

\section{AUTHOR CONTRIBUTIONS}

FB analyzed, discussed, and interpreted data and literature and wrote the manuscript; FM analyzed, discussed, and interpreted data and literature and contributed to manuscript preparation; AM supervised, discussed, and interpreted data and literature, verified data analysis, and wrote the manuscript.

\section{FUNDING}

This work was supported by grants awarded by Associazione Italiana Ricerca sul Cancro (AIRC): IG 2010 project no. 10225 (L.M.) and "Special Program Molecular Clinical Oncology 5L1000" project no. 9962 (L.M.); and Istituto Superiore di Sanita' (I.S.S.), Programma Nazionale di Ricerca sull'AIDS (2009-2010) project no. $40 \mathrm{H} 67$ (L.M.). Istituto Superiore di Sanita' (I.S.S.): Programma nazionale di ricerca sull'AIDS, Accordi di collaborazione scientifica 45G.11 (AM), 40H69 (AM); Ministero della Salute RF-2010-2316197 (AM).

12. Horowitz A, Strauss-Albee D, Leipold M, Kubo J, Nemat-Gorgani N, Dogan OC, et al. Genetic and environmental determinants of human NK cell diversity revealed by mass cytometry. Sci Transl Med (2013) 5(208):208ra145. doi:10.1126/scitranslmed.3006702

13. Bar-Ephraïm YE, Mebius RE. Innate lymphoid cells in secondary lymphoid organs. Immunol Rev (2016) 271(1):185-99. doi:10.1111/imr.12407

14. Geiger TL, Sun JC. Development and maturation of natural killer cells. Curr Opin Immunol (2016) 39:82-9. doi:10.1016/j.coi.2016.01.007

15. Jensen CT, Strid T, Sigvardsson M. Exploring the multifaceted nature of the common lymphoid progenitor compartment. Curr Opin Immunol (2016) 39:121-6. doi:10.1016/j.coi.2016.01.009

16. Kyoizumi S, Kubo YF, Kajimura J, Yoshida K, Imai K, Hayashi T, et al. Ageassociated changes in the differentiation potentials of human circulating hematopoietic progenitors to T- or NK-lineage cells. J Immunol (2013) 190(12):6164-72. doi:10.4049/jimmunol.1203189

17. Doulatov S, Notta F, Eppert K, Nguyen LT, Ohashi PS, Dick JE. Revised map of the human progenitor hierarchy shows the origin of macrophages and dendritic cells in early lymphoid development. Nat Immunol (2010) 11(7):585-93. doi:10.1038/ni.1889

18. Laurenti E, Doulatov S, Zandi S, Plumb I, Chen J, April C, et al. The transcriptional architecture of early human hematopoiesis identifies multilevel control of lymphoid commitment. Nat Immunol (2013) 14(7):756-63. doi:10.1038/ ni. 2615

19. Doulatov S, Eppert K, Nguyen LT, Ohashi PS, Dick JE. Revised map of the human progenitor hierarchy shows the origin of macrophages and dendritic cells in early lymphoid development. Nat Immunol (2010) 11(7):585-93. doi:10.1038/ni.1889

20. Yin T, Li L. The stem cell niches in bone. J Clin Invest (2006) 116(5):1195-201. doi:10.1172/JCI28568

21. Siewiera J, Gouilly J, Hocine HR, Cartron G, Levy C, Al-Daccak R, et al. Natural cytotoxicity receptor splice variants orchestrate the distinct functions of human natural killer cell subtypes. Nat Commun (2015) 6:10183. doi:10.1038/ncomms10183

22. Vacca P, Pietra G, Falco M, Romeo E, Bottino C, Bellora F, et al. Analysis of natural killer cells isolated from human decidua: evidence that 2B4 (CD244) 
functions as an inhibitory receptor and blocks NK-cell function. Blood (2006) 108(13):4078-85. doi:10.1182/blood-2006-04-017343

23. Klein Wolterink RG, Me G-O, Vosshenrich CAJ, Hendriks RW. The intrathymic crossroads of $\mathrm{T}$ and NK cell differentiation. Immunol Rev (2010) 238(1):126-37. doi:10.1111/j.1600-065X.2010.00960.x

24. Izon DJ. T-cell development: thymus-settling progenitors: settled? Immunol Cell Biol (2008) 86(7):552-3. doi:10.1038/icb.2008.50

25. Freud AG, Yu J, Caligiuri MA. Human natural killer cell development in secondary lymphoid tissues. Semin Immunol (2014) 26(2):132-7. doi:10.1016/j. smim.2014.02.008

26. Becknell B, Caligiuri MA. Interleukin-2, interleukin-15, and their roles in human natural killer cells. Adv Immunol (2005) 86:209-39. doi:10.1016/ S0065-2776(04)86006-1

27. Freud AG, Yokohama A, Becknell B, Lee MT, Mao HC, Ferketich AK, et al. Evidence for discrete stages of human natural killer cell differentiation in vivo. J Exp Med (2006) 203(4):1033-43. doi:10.1084/jem.20052507

28. Freud AG, Becknell B, Roychowdhury S, Mao HC, Ferketich AK, Nuovo GJ, et al. A human $\mathrm{CD} 34(+)$ subset resides in lymph nodes and differentiates into CD56bright natural killer cells. Immunity (2005) 22(3):295-304. doi:10.1016/j. immuni.2005.01.013

29. Grzywacz B, Kataria N, Sikora M, Oostendorp RA, Dzierzak EA, Blazar BR, et al. Coordinated acquisition of inhibitory and activating receptors and functional properties by developing human natural killer cells. Blood (2006) 108(12):3824-33. doi:10.1182/blood-2006-04-020198

30. Perussia B, Chen Y, Loza MJ. Peripheral NK cell phenotypes: multiple changing of faces of an adapting, developing cell. Mol Immunol (2005) 42(4):385-95. doi:10.1016/j.molimm.2004.07.017

31. Ouyang Q, Baerlocher G, Vulto I, Lansdorp PM. Telomere length in human natural killer cell subsets. Ann N Y Acad Sci (2007) 1106:240-52. doi:10.1196/ annals.1392.001

32. Grzywacz B, Kataria N, Kataria N, Blazar BR, Miller JS, Verneris MR. Natural killer-cell differentiation by myeloid progenitors. Blood (2011) 117(13):3548. doi:10.1182/blood-2010-04-281394

33. Costa P, Sivori S, Bozzano F, Martini I, Moretta A, Moretta L, et al. IFN- $\alpha$ mediated increase in cytolytic activity of maturing NK cell upon exposure to HSV-infected myelomonocytes. Eur J Immunol (2009) 39(1):147-58. doi:10.1002/eji.200838532

34. Mailliard RB, Alber S, Shen H, Watkins SC, Kirkwood JM, Herberman RB, et al. IL-18-induced CD83+CCR7+ NK helper cells. J Exp Med (2005) 202(7):941-53. doi:10.1084/jem.20050128

35. Beziat V, Liu L, Malmberg J-A, Ivarsson MA, Sohlberg E, Bjorklund AT, et al. NK cell responses to cytomegalovirus infection lead to stable imprints in the human KIR repertoire and involve activating KIRs. Blood (2013) 121(14):2678-88. doi:10.1182/blood-2012-10-459545

36. Yawata M, Yawata N, Draghi M, Little A-M, Partheniou F, Parham P. Roles for HLA and KIR polymorphisms in natural killer cell repertoire selection and modulation of effector function. JExp Med (2006) 203(3):633-45. doi:10.1084/jem.20051884

37. Spits H, Artis D, Colonna M, Diefenbach A, Di Santo JP, Eberl G, et al. Innate lymphoid cells - a proposal for uniform nomenclature. Nat Rev Immunol (2013) 13(2):145-9. doi:10.1038/nri3365

38. Moretta F, Petronelli F, Lucarelli B, Pitisci A, Bertaina A, Locatelli F, et al. The generation of human innate lymphoid cells is influenced by the source of hematopoietic stem cells and by the use of G-CSF. Eur J Immunol (2016) 46(5):1271-8. doi:10.1002/eji.201546079

39. Paust S, Gill HS, Wang B-Z, Flynn MP, Moseman EA, Senman B, et al. Critical role for the chemokine receptor CXCR6 in NK cell-mediated antigen-specific memory of haptens and viruses. Nat Immunol (2010) 11(12):1127-35. doi:10.1038/ni.1953

40. Sun JC, Lanier LL. Natural killer cells remember: an evolutionary bridge between innate and adaptive immunity? Eur J Immunol (2009) 39(8):2059-64. doi:10.1002/eji.200939435

41. Min-Oo G, Kamimura Y, Hendricks DW, Nabekura T, Lanier LL. Natural killer cells: walking three paths down memory lane. Trends Immunol (2013) 34(6):251-8. doi:10.1016/j.it.2013.02.005

42. Guma M, Angulo A, Vilches C, Gomez-Lozano N, Malats N, Lopez-Botet M. Imprint of human cytomegalovirus infection on the NK cell receptor repertoire. Blood (2004) 104(12):3664-71. doi:10.1182/blood-2004-05-2058
43. Guma M, Budt M, Saez A, Brckalo T, Hengel H, Angulo A, et al. Expansion of CD94/NKG2C+ NK cells in response to human cytomegalovirus-infected fibroblasts. Blood (2006) 107(9):3624-31. doi:10.1182/blood-2005-09-3682

44. Romo NMG, Muntasell A, Heredia G, Baía D, Angulo A, Guma M, et al. Natural killer cell-mediated response to human cytomegalovirus-infected macrophages is modulated by their functional polarization. JLeukoc Biol (2011) 90(4):717-26. doi:10.1189/jlb.0311171

45. Della Chiesa M, Falco M, Podesà M, Locatelli F, Moretta L, Frassoni F, et al. Phenotypic and functional heterogeneity of human NK cells developing after umbilical cord blood transplantation: a role for human cytomegalovirus? Blood (2011) 119(2):399-410. doi:10.1182/blood-2011-08-372003

46. Petitdemange $\mathrm{C}$, Becquart $\mathrm{P}$, Wauquier N, Béziat V, Debré $\mathrm{P}$, Leroy EM, et al. Unconventional repertoire profile is imprinted during acute chikungunya infection for natural killer cells polarization toward cytotoxicity. PLoS Pathog (2011) 7(9):e1002268. doi:10.1371/journal.ppat.1002268

47. Bjorkstrom NK, Lindgren T, Stoltz M, Fauriat C, Braun M, Evander M, et al. Rapid expansion and long-term persistence of elevated NK cell numbers in humans infected with hantavirus. J Exp Med (2011) 208(1):13-21. doi:10.1084/ jem. 20100762

48. Foley B, Cooley S, Verneris MR, Pitt M, Curtsinger J, Luo X, et al. Cytomegalovirus reactivation after allogeneic transplantation promotes a lasting increase in educated NKG2C+ natural killer cells with potent function. Blood (2012) 119(11):2665-74. doi:10.1182/blood-2011-10-386995

49. Rolle A, Pollmann J, Cerwenka A. Memory of infections: an emerging role for natural killer cells. PLoS Pathog (2013) 9(9):e1003548. doi:10.1371/journal. ppat. 1003548

50. Romee R, Schneider S, Leong JW, Chase JM, Keppel CR, Sullivan RP, et al. Cytokine activation induces human memory-like NK cells. Blood (2012) 120(24):4751-60. doi:10.1182/blood-2012-04-419283

51. Sun JC, Beilke J, Lanier LL. Adaptive immune features of natural killer cells. Nature (2009) 457(7229):557-61. doi:10.1038/nature07665

52. Cooper MA, Elliott J, Keyel PA, Yang L, Carrero JA, Yokoyama WM. Cytokineinduced memory-like natural killer cells. Proc Natl Acad Sci U S A (2009) 106(6):1915-9. doi:10.1073/pnas.0813192106

53. Hu PF, Hultin L, Hultin P, Hausner MA, Hirji K, Jewett A, et al. Natural killer cell immunodeficiency in HIV disease is manifest by profoundly decreased numbers of CD16+CD56+ cells and expansion of a population of CD16dimCD56- cells with low lytic activity. J Acquir Immune Defic Syndr Hum Retrovirol (1995) 10(3):331-40. doi:10.1097/00042560-199511000-00005

54. Björkström NK, Ljunggren H-G, Sandberg JK. CD56 negative NK cells: origin, function, and role in chronic viral disease. Trends Immunol (2010) 31(11):401-6. doi:10.1016/j.it.2010.08.003

55. Le Bouteiller P, Siewiera J, Casart Y, Aguerre-Girr M, El Costa H, Berrebi A, et al. The human decidual NK-cell response to virus infection: what can we learn from circulating NK lymphocytes? J Reprod Immunol (2011) 88(2):170-5. doi:10.1016/j.jri.2010.12.005

56. Lash GE, Robson S, Bulmer JN. Review: functional role of uterine natural killer (uNK) cells in human early pregnancy decidua. Placenta (2010) 31(Suppl):S87-92. doi:10.1016/j.placenta.2009.12.022

57. Koopman LA, Kopcow H, Rybalov B, Boyson JE, Orange JS, Schatz F, et al. Human decidual natural killer cells are a unique NK cell subset with immunomodulatory potential. J Exp Med (2003) 198(8):1201-12. doi:10.1084/ jem.20030305

58. Moffett-King A. Natural killer cells and pregnancy. Nat Rev Immunol (2002) 2(9):656-63. doi:10.1038/nri967

59. Tabiasco J, Rabot MF, Aguerre-Girr M, El Costa H, Berrebi A, Parant $\mathrm{O}$, et al. Human decidual NK cells: unique phenotype and functional properties - a review. Placenta (2006) 27(Suppl A):S34-9. doi:10.1016/j. placenta.2006.06.003

60. Bozzano F, Marras F, Ascierto ML, Cantoni C, Cenderello G, Dentone C, et al. 'Emergency exit' of bone-marrow-resident CD34(+)DNAM-1(bright) CXCR4(+)-committed lymphoid precursors during chronic infection and inflammation. Nat Commun (2015) 6:8109. doi:10.1038/ncomms9109

61. Kunisaki Y, Bruns I, Scheiermann C, Ahmed J, Pinho S, Zhang D, et al. Arteriolar niches maintain haematopoietic stem cell quiescence. Nature (2013) 502(7473):637-43. doi:10.1038/nature12612

62. Greenbaum A, Hsu Y-MS, Day RB, Schuettpelz LG, Christopher MJ, Borgerding JN, et al. CXCL12 in early mesenchymal progenitors is required 
for haematopoietic stem-cell maintenance. Nature (2013) 495(7440):227-30. doi:10.1038/nature11926

63. Ding L, Morrison SJ. Haematopoietic stem cells and early lymphoid progenitors occupy distinct bone marrow niches. Nature (2013) 495(7440):231-5. doi:10.1038/nature11885

64. Kollet O, Dar A, Shivtiel S, Kalinkovich A, Lapid K, Sztainberg Y, et al. Osteoclasts degrade endosteal components and promote mobilization of hematopoietic progenitor cells. Nat Med (2006) 12(6):657-64. doi:10.1038/ nm1417

65. Takayanagi H. Osteoimmunology: shared mechanisms and crosstalk between the immune and bone systems. Nat Rev Immunol (2007) 7(4):292-304. doi:10.1038/nri2062

66. Kulak CA, Borba V, Jorgetti V, Dos Reis LM, Liu XS, Kimmel DB, et al. Skeletal microstructural abnormalities in postmenopausal women with chronic obstructive pulmonary disease. J Bone Miner Res (2010) 25(9):1931-40. doi:10.1002/jbmr.88

67. Sivori S, Cantoni C, Parolini S, Marcenaro E, Conte R, Moretta L, et al. IL-21 induces both rapid maturation of human $\mathrm{CD} 34+$ cell precursors towards $\mathrm{NK}$ cells and acquisition of surface killer Ig-like receptors. Eur J Immunol (2003) 33(12):3439-47. doi:10.1002/eji.200324533

68. Alter G, Jost S, Rihn S, Reyor LL, Nolan BE, Ghebremichael M, et al. Reduced frequencies of NKp30+NKp46+, CD161+, and NKG2D+ NK cells in acute
HCV infection may predict viral clearance. J Hepatol (2011) 55(2):278-88. doi:10.1016/j.jhep.2010.11.030

69. Wu C, Li B, Lu R, Koelle Samson J, Yang Y, Jares A, et al. Clonal tracking of rhesus macaque hematopoiesis highlights a distinct lineage origin for natural killer cells. Cell Stem Cell (2014) 14(4):486-99. doi:10.1016/j.stem. 2014.01.020

70. Rutjens E, Mazza S, Biassoni R, Koopman G, Ugolotti E, Fogli M, et al. CD8+ NK cells are predominant in chimpanzees, characterized by high NCR expression and cytokine production, and preserved in chronic HIV-1 infection. Eur J Immunol (2010) 40(5):1440-50. doi:10.1002/ eji.200940062

Conflict of Interest Statement: The authors declare that the research was conducted in the absence of any commercial or financial relationships that could be construed as a potential conflict of interest.

Copyright (๑) 2017 Bozzano, Marras and De Maria. This is an open-access article distributed under the terms of the Creative Commons Attribution License (CC BY). The use, distribution or reproduction in other forums is permitted, provided the original author(s) or licensor are credited and that the original publication in this journal is cited, in accordance with accepted academic practice. No use, distribution or reproduction is permitted which does not comply with these terms. 